\title{
Élisabeth Roudinesco (2011). Lacan: In Spite of everything, translated by Gregory Elliott in 2014 (London and New York: Verso), pp. 160, ISBN 978-1-78168-162-6
}

\author{
Shiva Kumar Srinivasan \\ Behavioral Sciences, International Institute of Planning and Management, Chennai, India
}

\begin{abstract}
This book argues that the work of the French psychoanalyst Jacques Lacan remains relevant 'in spite of everything' that his detractors have done to belittle it. The sixteen essays in the book set to explain why this is the case. This book can be generically termed as a 'transferential memoir' that seeks to explore the 'poetics' of the analytic transference. Élisabeth Roudinesco's main goal is to work-through her transference to the Lacanian project of a 'return to Freud', and explain to contemporary readers how and why Lacan re-invented psychoanalysis after the two world wars; and why a merely technocratic approach to analysis is misplaced given the horrendous reality of antiSemitism and genocide that was triggered off during the war years. It is therefore important she argues to think through the Freudian insight about the pervasiveness of the death instinct within a theory of analytic metapsychology. This will help her readers to understand why the later Lacan invokes the figures of Antigone against Oedipus and the Marquis de Sade with Kant to forge a model of desire that can accommodate the death instinct rather than negate it in the interests of bourgeois propriety or the service of goods.
\end{abstract}

Keywords: Case History, Death Instinct, Psychoanalysis, Subject Presumed to Know, Transference

\section{Introduction}

What does the phrase 'in spite of everything' mean in the title? This is the first question that will strike a reader when he opens this book. The reason for that must be obvious. Élisabeth Roudinesco is best known for a three-volume history of psychoanalysis in France, and is a leading expert on the work of the French psychoanalyst, Jacques Marie Émile Lacan (1901-1981). It appears at first sight that this book is an attempt to supplement the history of psychoanalysis with some material that Roudinesco was not able to incorporate in the previous volumes. A closer examination of this book however reveals that this is not the case at all. Another possibility could be that the book is a collection of essays that are not as empirical in their orientation as the chapters of the first three volumes, and that is all there is to it. These sixteen essays are more in the way of Roudinesco's opinions on a range of issues pertaining to 'the Freudian field' in France rather than an attempt at another volume of psychoanalytic history. While there is an element of truth in the latter interpretation, I think there is a better way of reading this book. The main clue that the reader is looking for to situate this book is the fact that the title is, in a sense, incomplete. What does 'in spite of everything' mean? What would the full formulation of the title really be like? I think if we unpack the title, we will get something like this: Jacques Lacan continues to be the 'subject presumed to know in spite of everything' that has been said about him by his detractors. In order to understand the title then the reader must be acquainted with the notion of the 'subject presumed to know'. The main wager in the psychoanalytic clinic of Jacques Lacan is that the psychoanalyst is in the locus of the subject presumed to know (Lacan, 1979). What does the analyst know? What the analyst knows is the secret of the patient's desire. It is therefore within the analyst's ability to steer the patient in the direction of his desire provided the patient is willing to work within the existential assumption that the analyst is the 'subject presumed to know' (Evans, 1996a). If this assumption is firmly in place, it is known as a positive transference. If this assumption is not in place or the patient makes this assumption only every now and then the transference is thought to be negative. All analyses will include both positive and negative elements, and the analyst should be able to help his patient even when negative elements appear in the transference (Laplanche and Pontalis, 1973, 1988). At the end of the analysis, the patient 'de-supposes' the analyst from the locus of the subject presumed to know, the analysis is brought to an end, and the patient gets on with his life. This is the usual trajectory of the analysis if all goes well (Evans, 1996b). 


\section{A Transferential Memoir}

The affective dynamics that constitute these stages of the transference are not only restricted to the psychoanalytic clinic, but can also be observed in a number of relationships in schools, colleges, firms, hospitals, and so on where professionals engage with their clients and students. Or, to put it in other words, the transference can be clinical, professional, or even cultural in its orientation; these forms of the transference are known as 'extra-mural'. So the phrase 'in spite of everything' means that despite the controversies that agitated the psychoanalytic community in Jacques Lacan's attempts to re-invent Freudian psychoanalysis in France, he still remains the most important point of reference for anybody who wants to engage seriously with Freudian meta-psychology, the literary representations of the psyche, the philosophical import of the unconscious within theories of the mind, and so on (Leupin, 1991). This is analogous to what Lacan himself might have thought about the work of Sigmund Freud when he began his career in psychiatry. Lacan must have told himself that despite all the theoretical controversies in which Freudian psychoanalysis first found itself in Austria, Germany, the United States, and France, the texts of Freud remain the cornerstone of the analytic edifice 'in spite of everything'. This is because the work of Sigmund Freud and Jacques Lacan are, in the language of Michel Foucault, 'trans-discursive', i.e. their theoretical work is not reducible to the formal categories that they deploy or invoke, but have paradigmatic implications for a range of disciplines that are trying to make sense of the human mind, psyche, or behavior (Foucault, 1984). The phrase 'in spite of everything' can also be construed as implying that the reader does not have to be a clinician or a patient to put Lacan in the locus of the subject presumed to know since a great deal of contemporary French culture is based on this assumption. Another way of putting this across is to say that it doesn't matter whether the reader personally likes or dislikes Lacan as a person since 'in spite of everything' that we know or don't know about him, he is more of a locus than a person about whom we can have agreements or disagreements. So, in that sense, the information about Lacan's personal life is not invoked in the immediate sense in which biographers use such forms of information. There are important biographical elements in Roudinesco's depiction of Lacan, but this is not a biography in the conventional sense of the term where she is trying to make her subject more 'likeable' or make a Lacanian out of the reader. I think the phrase that most accurately represents this book is a 'transferential memoir'. It is Roundinesco's way of working-through her socio-cultural transference to the personality or persona of Jacques Lacan. A transferential memoir, unlike an empirical memoir involving historical figures, is not necessarily based on actual interactions and meetings. It is to be construed instead as an attempt to open up psychic space for thinking in ways that might otherwise not have been transferentially possible. What Roudinesco is doing in this book, in other words, is to try and explain to us how she has inhabited the Freudian field in France, and how that has made a difference to her career, life, and sense of professional well-being (Soler, 2002). It is in that sense that Lacan is supposed to have told his followers, 'It is up to you to be Lacanians. As far as I am concerned, I am a Freudian'. Or, that in spite of everything, Lacan himself remained a Freudian all his life (Adam, 2002; Lacan, 2007).

\section{Poetics of the Transference}

An important aspect of a transferential memoir is that it seeks to invoke a positive affective dynamics as the motor-force of human behavior. Roudinesco's approach in each of these essays is to work-through not so much the affects induced by her transference to Lacan, but its poetics. So, in that sense, it doesn't matter whether she has actually met Lacan often enough like a patient in a long analysis. I use the term 'poetics' in the sense that her transference to Lacan helps her to structure all her experiences as a dynamic response to his interventions in the history of psychoanalysis in France. Roudinesco is not taking the position of empiricist historians who pretend to be immune to the transferential dynamics induced by the person they are writing about in their histories. Instead, her approach is to say that there is greater intellectual honesty in being aware of the transferential vicissitudes that constitute the attempt to make sense of the history of psychoanalysis, given especially the fact that Lacan's persona was larger than life and deliberately calculated to be so. These aspects of Roudinesco's transference become obvious when she goes through the different 'places, objects, and books' that constitute the material aspects of her transference to Lacan. While this may seem to be a common feature to all biographers - how else can they stick it out year after year with those endless laundry lists of items about their subject - it is something that Roudinesco is quite conscious of as constituting her transference because she is not impatient with these details including whole catalogues of books that Lacan assembled at home, but actually revels in them. Amongst the objects that Roundinesco mentions are the clinics that Freud and Lacan practiced in Vienna, London, and Paris. These have now been designated as museums, and the décor of these clinics have been maintained in a way that will give a visitor a feel for what it must have been like to be in analysis during the heydays of psychoanalysis before patients began to behave like customers or clients. Roudinesco's sense of nostalgia for an era which had sufficient privacy to do analysis has important implications for the case method and the fact that the genre of the case serves, as John Forrester has pointed out, as a basic unit of analysis in Freudian metapsychology (Forrester, 1996; Forrester, 2007). We however find ourselves in an era when patients 
do not like to be depicted in analytic case histories at all and are willing to take legal action against analysts if they find themselves depicted in too much detail; analysts are therefore content to merely write 'micronarratives intended to illustrate some particular aspect of a clinical orientation'. Compare this to the extraordinary amount of tolerance Freud's patients must have had - not only did they not mind being depicted in case histories, but they were also willing to serve as living embodiments of the Freudian archive in the history of psychoanalysis (Derrida, 1996). It was not unusual for Freud's early biographers to meet with and interview his analysands whenever possible: some of these analysands were patients and some were trainee analysts and they were conscious of the fact that they were making clinical history in a way that the contemporary patient doesn't necessarily feel. The forms of transference that we associate with the patients in the Freudian case histories is obviously of a different order altogether from what we refer to as a positive transference now (Ferenczi, 1973; Schwartz, 1999). The weakening of the transferential order of affective relations in the contemporary clinic is analogous to the loss of patriarchal authority within familial structures (Zeldin, 1999). Any rigorous compareand-contrast between the Freudian and Lacanian depictions of paternal authority will make this obvious. Even when Lacan invokes categories like the 'name-of-the-father', he is at pains to invoke the paternal function or the paternal locus within anthropological models of kinship structure since he knew well (as a reader of Paul Claudel) that the contemporary father cannot embody the classical notion of paternal authority that was the staple feature in the history of the family in the Judeo-Christian world (Roudinesco, 1997).

\section{The Death Instinct}

Roudinesco is at pains to point out that Lacan's analytic orientation was deeply affected by the world wars. It didn't make much sense to him to take merely a technocratic orientation to analysis since the large scale slaughter of human beings in these wars forces the issue of whether there is something inherently bad in human nature that is precipitated during such events. This question of how to theorize the death instinct was also related to the problem of anti-Semitism, the death camps at Auschwitz and in many other parts of the Nazi empire, the trial of Adolf Eichmann (who seemed completely without remorse for his actions during the Holocaust) at Jerusalem, and the Freudian preoccupation with the endemic conflict between Eros and Thanatos in the psyche. Lacan believed that it would be unethical for psychoanalysis to proceed with a technocratic approach to the psyche as though nothing had happened or as though the wars were merely an historical aberration and that it would soon be back to normal in the Freudian clinic. What he wanted to do was nothing less than to rethink the conceptual structure of psychoanalysis by asking why analysts had not been able to adequately anticipate these wars, and what the lessons might be for the ethics of psychoanalysis going forward. These events prompted a turning to Greek tragedy, especially the plays of Sophocles in the Theban cycle, to reconstruct the mythical sources of psychoanalysis. It was not only Lacan who did this, but a number of French existentialists like JeanPaul Sartre and Albert Camus. That is why Lacan substitutes Oedipus with Antigone and reads Kant in juxtaposition with the Marquis de Sade. While these moves may take the reader initially by surprise they are an attempt to go beyond a sanitized model of psychoanalysis which had managed to lexicalize the Oedipus myth within the safe confines of bourgeois society. The Lacanian turn to ethics then is an attempt to pose the more fundamental question of what it means to either act upon or evade the desire that haunts the subject of analysis. Lacan felt that the ethics of psychoanalysis is not reducible to the service of goods in a bourgeois society since desire is not reducible to consumerism. It is instead to be construed as a way of asking the subject of analysis to rethink all his choices and decisions. The goal of doing this is to prepare the subject of analysis for the day of Last Judgment when he will have to take responsibility for why he did not act on his desire. The only thing that the subject of analysis can be blamed for, according to Lacan, is giving way, or ceding on his desire. Antigone then becomes a heroic symbol of both resistance and intransigence who is willing to stand her ground; she is both the figure which represents the transgression of the familial order 'and the remedy for that transgression' in a world that cannot anymore be in denial about the ever pervasive threat of genocide. Likewise, Lacan feels compelled to invoke the Marquis de Sade and juxtaposes him against a philosopher like Kant in order to forge a model of desire that can accommodate the death instinct rather than negate it in the interests of bourgeois propriety or the service of goods. This book, I conclude, will force a rethink on what it means to do psychoanalysis in a way that is historically nuanced rather than succumb to the temptation of reducing it to a mere collection of clinical techniques. Incidentally, it is precisely this problem of technique versus poetics that prompted Lacan to attempt his 'return to Freud' in the first place.

\section{References}

[1]. J. Adam. The meaning of the return to the Lacanian field: Lacan, Freud, Foucault, analysis 11, 2002, 91-98.

[2]. J. Derrida. Archive fever: A Freudian impression, translated by E. Prenowitz (Chicago and London: The University of Chicago Press, 1996)

[3]. D. Evans. Desire of the analyst, An introductory dictionary of Lacanian psychoanalysis (London and New York: Routledge, 1996a), 39-40.

[4]. D. Evans. End of the analysis, An introductory dictionary of Lacanian psychoanalysis (London and New York: Routledge, 1996b), 53-55. 
[5]. S. Ferenczi. Freud's influence on medicine, The first Freudians (New York: Jason Aronson, 1973), 16-31

[6]. J. Forrester. If $p$, then what? Thinking in cases, History of the Human Sciences, 9(3), 1996, 1-25.

[7]. J. Forrester. On Kuhn's case: Psychoanalysis and the paradigm, Critical Inquiry, 33, summer 2007, 782-819.

[8]. M. Foucault. What is an author? The Foucault reader, edited by P. Rabinow (New York: Pantheon Books, 1984), 101-120.

[9]. J. Lacan. Of the subject who is supposed to know, of the first dyad and the good, The four fundamental concepts of psychoanalysis (London: Penguin Books, 1979), translated by A. Sheridan, edited by J-A Miller, 230-243.

[10]. J. Lacan. The Lacanian field, The other side of psychoanalysis: The seminar of Jacques Lacan Book XVII, translated by R. Grigg (New York and London: W.W. Norton, 2007), 69-83.

[11]. J. Laplanche and J-B Pontalis. Transference, The language of psychoanalysis, translated by D. Nicholson-Smith (Karnac Books: The Institute of Psychoanalysis, London, 1973, 1988), 455-462.

[12]. A. Leupin (Editor). Lacan and the human sciences (Lincoln: University of Nebraska Press, 1991).

[13]. E. Roudinesco. Structure and the name-of-the-father, Jacques Lacan, translated by B. Bray (Cambridge: Polity Press, 1997), 260290.

[14]. J. Schwartz. Transference, Cassandra's daughter: A history of psychoanalysis (London: Penguin Books, 1999), 130-143.

[15]. C. Soler. Symptoms of transference, analysis, 11, 2002, 60-73.

[16]. T. Zeldin. Why fathers and their children are changing their minds about what they want from each other, An intimate history of humanity (London: Penguin Books, 1999), 297-310. 